\title{
THE RELATIONSHIP BETWEEN THE INTEREST OF LEARNING, PARENTS ATTENTION AND THE NUMERICAL SKILLS WITH STUDENTS MATHEMATICS LEARNING OUTCOMES OF SMA NEGERI 1 SAPURAN
}

\author{
Diyah Istriani ${ }^{\mathrm{a}}$, Suparman ${ }^{\mathrm{b}}$ \\ Program Studi Pendidikan Matematika Universitas Ahmad Dahlan \\ Jalan Ring Road Selatan, Tamanan, Banguntapan, Bantul Yogyakarta \\ adiyahistriani@gmail.com, ${ }^{\text {, }}$ suparman.uad@gmail.co.id
}

\begin{abstract}
The results of mathematics students learning associated with many factors. Interest in learning, parent's attention, and numerical skills are a variety of factors that were related to student mathematics learning outcomes. Therefore, this study aimed to determine the relationship between interest in learning, attention parents and numerical skills with mathematics students learning outcomes of class X MIPA SMA Negeri 1 Sapuran Wonosobo district at academic year 2015/2016. The population in this study were all students of class X MIPA SMA Negeri 1 Sapuran comprising five classes with the number of population in this study were 129 students, the sample is class X MIPA 2 totaling 27 students, as well as the technique of sampling with random sampling technique to class. Techniques of data collection was conducted by questionnaire to determine interest in learning and attention from their parents, as well as the test method to determine the ability of numerical and mathematical learning outcomes of students. To test the validity of the instruments used to test the validity, reliability test and different power. After all the data collected do the data analysis techniques including normality test, linearity test, and independent testing. Analysis of data to test the hypothesis by using product-moment correlation and multiple linear regression analysis. The results showed that there was a positive and significant correlation between interest in learning, parents attention and numerical skills with mathematics learning outcomes at a significant level of $5 \%$ with a multiple correlation coefficient $(r)=$ 0,608437111 and arithmetic $F=4,506427241$ greater than table $\mathrm{F}=3.05$, relative contribution $x_{1}=37,768747 \%$, the relative contribution $x_{2}=57,427981 \%$ and the relative contributions $x_{3}=$ $4,803272 \%$ and the effective contribution $x_{1}=13,98183 \%$, the effective contribution $\mathrm{X}_{2}=$ $21,259593 \%$ and the effective contribution $\mathrm{X}_{3}=1,77815 \%$.
\end{abstract}

Keywords: Interest in Learning, Parents Attention, Numerical Skills, Learning Outcome

\section{INTRODUCTION}

At present, the world of education is being rocked by various changes by the demands and the community and is challenged to be able to answer various local problems and rapid global changes. However, education in the context of regional autonomy is expected to take a role in realizing the function and purpose of education of Law No. 3 of 2003 concerning the National Education System article 3 below: National education functions to develop capabilities and shape dignified national character and civilization in order educating the nation's life, aims to develop the potential of students to become human beings who believe and fear God Almighty, have a noble character, are healthy, knowledgeable, competent, creative, independent, and become democratic and responsible citizens. "The quality of education is always a concern of various circles of society. Based on information from one mathematics teacher at SMA N 1 Sapuran the interest in learning mathematics in students is diverse, which results in students still having difficulties in learning mathematics. Interest in learning has a great effect on learning outcomes because if the learning material is not by student interests, students will not learn as well as possible. According to Ahmadi, Abu and Widodo Supriyono (2013: 87) state that learning requires guidance from parents so that adult attitudes and responsibilities of learning grow in children. Learning success of children in school is not only an effort of the teacher and child as students, but the alignments of parents who provide support in the form of attention, encouragement, and supervision to their children to study at home contribute. Based on information obtained from students, parents tend to rarely tell their children to study. It can be concluded that 
parents care less about their children. In learning children need to get encouragement and attention from parents.

Numerical abilities are needed by students to do calculations or operate numbers. So that with numerical abilities, students can solve math problems easily and smoothly. According to one math teacher, students' numeracy skills are still low. It was seen when given the question, some were still cheating while working on a problem which he thought was difficult. The good and bad quality of learning is seen from student learning outcomes. According to Sudjana, Nana (2012: 22) defines learning outcomes are abilities possessed by students after he receives his learning experience. Where learning outcomes themselves are learning outcomes achieved after going through the process of teaching and learning activities. Learning outcomes can be shown through the value given by a teacher from the number of fields of study that have been studied by students. Based on information from students of SMA 1 Sapuran, some students consider math lessons difficult. Because it is difficult, students tend to be lazy to learn it. Therefore it has an impact on mathematics learning outcomes which tend to below. The low mathematics learning outcomes of class X MIPA SMA Negeri 1 Sapuran can be seen from the average mathematics scores at the end of semester exams are still low. The math score for the final semester X MIPA exam at SMA 1 Sapuran is more than $50 \%$ below the MCC (minimum completion criteria) standard. This proves that there are still many students who have difficulty learning mathematics.

Based on the background and limitations of the problem, then the problem can be formulated to be examined, namely is there a positive and significant relationship between interest in learning, parental attention and numerical ability with the mathematics learning outcomes of class X MIPA SMA 1 Sapuran 2015/2016 school year?

The purpose of this study is to find out whether there is a positive or significant relationship between learning intentions, parental attention and numerical abilities with the mathematics learning outcomes of students of class X MIPA in SMA 1 Sapuran 2015/2016 academic year?

\section{METHODS}

This research is classified as quantitative research. The place of research was conducted at Sapuran 1 Public High School. While the time of the study was carried out in the even semester of the 2015/2016 academic year. The population in this study were all students of class X MIPA SMA 1 Sapuran consisting of 5 classes. In this study, samples were taken randomly using random sampling techniques for the class. It was said to be random because the sample taking was done randomly from the existing class. After all, the ability of each class in the population was the same and what was taken as the sample class was class X MIPA 2 with students as many as 27 students.

The research variables are two variables, namely the independent variable (independent) and the dependent variable (dependent). Independent variable (Independent) consists of an interest in learning (X1), parental attention (X2) and numerical ability (X3), while the dependent variable is the learning outcomes of mathematics (Y). Data collection techniques used questionnaires and test methods. In this study, the questionnaire method was used to obtain data on the interest in learning and the attention of parents of students. While the test method is used to obtain data on numerical abilities and mathematics learning outcomes of students of class X MIPA in SMA Negeri 1 Sapuran.

The questionnaire instrument test used the content validity test by the reviewer and the instrument reliability test with alpha formula, while the question instrument test used the instrument validity test with product-moment correlation technique, different power test and instrument reliability test with the KR-20 formula (Suharsimi Arikunto. 2009: 100 ) After the data is collected, an analysis prerequisite test that must be fulfilled includes normality test, linearity test, and independence test. Data analysis using product-moment correlation analysis and multiple linear regression analysis. 


\section{RESULTS AND DISCUSSION}

In this section, a further discussion of the results of the study was analyzed correlation. This study found that the seventh hypothesis test results were a positive and significant relationship between interest in learning, parental attention and numerical abilities of students with mathematics learning outcomes. In other words, the better the students' interest in learning, the better the learning outcomes will be. Likewise, with the attention of parents, the higher parents give attention to their children as much as possible, the higher the learning outcomes. Besides, numerical abilities also affect learning outcomes, because if numerical abilities are high, the learning outcomes will also be higher.

In this study also uses analysis prerequisite tests which include:

1. Test for normality

This normality test is used to test the distribution of data obtained by each variable whether it is normally distributed or not. The summary results of the normality test of the four variables are:

\begin{tabular}{|l|l|l|l|l|l|}
\hline No & Variable & $\boldsymbol{\chi}_{\text {count }}^{\mathbf{2}}$ & $\boldsymbol{\chi}_{\text {table }}^{\mathbf{2}}$ & Df & Info \\
\hline 1 & Interest to learn $\left(X_{1}\right)$ & 3,1666 & 7,8150 & 4 & Normal \\
\hline 2 & Parents attention $\left(X_{2}\right)$ & 2,1275 & 5,9910 & 3 & Normal \\
\hline 3 & Numerical Ability $\left(X_{3}\right)$ & 7,4447 & 7,8150 & 4 & Normal \\
\hline 4 & Mathematics Learning Results $(Y)$ & 4,9425 & 5,9910 & 3 & Normal \\
\hline
\end{tabular}

2. Test of independence

Independence test is used to find out whether or not there is a relationship between independent variables. The summary of the independence test results from the three independent variables are:

\begin{tabular}{|c|c|c|c|c|c|}
\hline No & Variable & $\chi_{\text {count }}^{2}$ & $\chi_{\text {table }}^{2}$ & Df & Info \\
\hline 1 & $X_{1}$ to $X_{2}$ & 226,036 & 337,652 & 25 & Independent \\
\hline 2 & $X_{1}$ to $X_{3}$ & 222,949 & 337,652 & 25 & Independent \\
\hline 3 & $X_{2}$ to $X_{3}$ & 224,836 & 337,652 & 25 & Independent \\
\hline
\end{tabular}

3. Test linearity

Linearity test is used to find out between the independent variable and the dependent variable whether it has a linear relationship or not. The summary results of the linearity test of the four variables are:

\begin{tabular}{|l|c|c|c|c|}
\hline No & Variable & $\boldsymbol{F}_{\text {count }}$ & $\boldsymbol{F}_{\text {table }}$ & Info \\
\hline 1 & $X_{1}$ to $Y$ & 0,4104 & 2,8450 & Linear \\
\hline 2 & $X_{2}$ to $Y$ & 0,3915 & 2,7386 & Linear \\
\hline 3 & $X_{3}$ to $Y$ & $-0,4705$ & 2,5655 & Linear \\
\hline
\end{tabular}

4. Test the Hypothesis

From the multiple correlation analysis obtained multiple correlation coefficient values $(R)$ is 0,6084 . In this study also obtained a coefficient of determination $\left(R^{2}\right)$ is 0,3702 meaning the variance of mathematics learning outcomes $(Y)$ which can be explained by an interest in learning $\left(\mathrm{X}_{1}\right)$, parents attention $\left(\mathrm{X}_{2}\right)$, and numerical abilities $\left(X_{3}\right)$ through a linear line $\hat{Y}=27,43229+$ $0,250473 X_{1}+0,360091 X_{2}+0,053347 X_{3}$. This means an increase in one unit $\left(\mathrm{X}_{1}\right)$ result in $0,250473 \mathrm{Y}$ increase, one unit increase $\left(\mathrm{X}_{2}\right)$ result in 0,360091 increase, one unit increase $\left(\mathrm{X}_{3}\right)$ result in $0,053347 \mathrm{Y}$ increase. As for relative donations $\mathrm{X}_{1}$ is $37,768747 \%, \mathrm{X}_{2}$ is $57,427981 \%$ and $X_{3}$ is $4,803272 \%$ and effective donations $X_{1}$ is equal to $13,98183 \%, X_{2}$ is $21,259593 \%$ and $\mathrm{X}_{3}$ is $1,77815 \%$. This shows that parental attention provides a more significant relationship to mathematics learning outcomes compared to interest in learning and numerical abilities. 


\section{CONCLUSION}

Based on the results of the research and discussion as outlined above, it can be concluded that there is a positive and significant relationship between interest in learning, parental attention and numerical ability with the mathematics learning outcomes of class X MIPA SMA 1 Sapuran 2015/2016 academic year. This is indicated by the - F test which is $F_{\text {count }}>F_{\text {table }}$ or 4,506427241 $>3,05$ with a multiple correlation coefficient $(\mathrm{R})$ of 0,608437111 and coefficient of determination $\left(R^{2}\right)$ is0,370195718. Linear regression equation $\hat{Y}=27,43229+0,250473 X_{1}+0,360091 X_{2}+$ $0,053347 X_{3}$. Relative contribution amount $X_{1}$ is $37,768747 \%, X_{2}$ is $57,427981 \%$ dan $X_{3}$ is $4,803272 \%$ and effective donations $X_{1}$ is $13,98183 \%, X_{2}$ is $21,259593 \%$ and $X_{3}$ is $1,77815 \%$.

\section{REFERENCES}

Ahmadi, Abu dan Widodo Supriyono. (2013). Psikologi Belajar. Jakarta:Rineka Cipta Arikunto, Suharsimi. (2006). Manajemen Penelitian. Jakarta: Rineka Cipta (2009). Dasar-dasar Evaluasi Pendidikan. Jakarta: Bumi Aksara (2013). Prosedur Penelitian Suatu Pendekatan Praktik. Jakarta: Rineka Cipta.

Astuti, Dessy. (2008). Hubungan Perhatian Orang Tua dan Kemandirian Belajar dengan Pretasi Belajar Matematika Siswa SMP Muhammadiyah 5 Yogyakarta Tahun Ajaran 2008/2009. Yogyakarta: Skripsi UAD

Bagus, Indra Leksana. (2011). Pengaruh Perhatian Orang Tua dan Kemandirian Belajar Siswa terhadap Prestasi Belajar Matematika Siswa Kelas VII Semester II SMP Muhammadiyah Pleret Kabupaten Bantul Tahun Ajaran 2011/2012. Yogyakarta: Skripsi UAD

Djamarah, Syaiful Bahri. (2011). Psikologi Belajar. Jakarta: Rineka Cipta

Fudyartanta, Ki. (2010). Tes Bakat dan Penskalaan Kecerdasan. Yogyakarta: Pustaka Pelajar

Galuh, Eka Permana. (2013) . Hubungan Perhatian Orang Tua Siswa, Lingkungan Belajar di Sekolah, dan Kemampuan Numerik dengan Hasil Belajar Matematika Siswa Kelas VII Semester Genap SMP Muhammadiyah 02 Gamping Kabupaten Sleman Tahun Ajaran 2013/2014. Yogyakarta: Skripsi UAD

Herijoko. (2010). http://www. herijoko2010.blogspot.co.id/2011/11/1.html. diunduh tanggal 11 November 2015 pukul 21.04

Khasanah, Uswatun. (2014). Analisis Regresi. Yogyakarta: UAD Press

Kurnianto, Fandi. (2013). Hubungan Minat Belajar dan Interaksi Teman Kelas dengan Hasil Belajar Matematika Siswa Kelas VII SMP Negeri Se-Kecamatan Girisubo Kabupaten Gunung Kidul Semester Genap Tahun Ajaran 2013/2014. Yogyakarta: Skripsi UAD

Purwanto M.Ngalim. (2013). Psikologi Pendidikan. Bandung: Rosda Karya

Rahmawati, Putri. (2014). Hubungan antara Perhatian Orang Tua, Kemampuan Numerik dan Motivasi Belajar Matematika dengan Hasil Belajar Matematika Siswa Kelas VII SMP Negeri 1 Temanggung Semester Ganjil Tahun Ajaran 2014/2015. Yogyakarta: Skripsi UAD

Rani, Dyah Widiyarsih. (2010). Pengaruh Minat Belajar dan Penggunaaan Sumber Belajar terhadap Hasil Belajar Matematika Siswa Kelas VIII Semester Genap SMP Negeri 2 Kabupaten Wonosobo Tahun Ajaran 2010/2011. Yogyakarta: Skripsi UAD

Sardiman, A.M. (2011). Interaksi dan Motivasi Belajar Mengajar. Jakarta: PT. Raja Grafindo Persada

Slameto.(2010). Belajar dan Faktor-Faktor yang Mempengaruhi.Jakarta: Rineka Cipta

Sudjana, Nana. (2012). Penilaian Hasil Proses Belajar Mengajar. Bandung: Remaja Rosdakarya

Sugiyono. (2012). Metode Penelitian Pendidikan. Bandung: Alfabeta

(2010). Statistika Untuk Penelitian. Bandung: ALFABETA

Suherman, Erman, dkk. (2003). Strategi Pengajaran Matematika Kontemporer. Jakarta: Universitas Pendidikan Indonesia

Suparman. (2012). Metodologi Penelitian Pendidikan. Yogakarta: MIPA UAD Press

Suraprana, Sumarna. (2009). Analisis Validitas Reliabilitas dan Interprestasi Hasil Tes Implementasi Kurikulum 2004. Bandung : Remaja Rosdakarya 
Suryabrata, Sumadi. (2013). Psikologi Pendidikan. Jakarta: Rajawali Pers

Undang- Undang. (2003). Undang- Undang Nomor 20, Tahun 2003, tentang Sistem Pendidikan Nasional

Walgito, Bimo. (2010). Bimbingan dan Konseling. Yogyakarta : Andi Offset (2010). Pengantar Psikologi Umum. Yogyakarta : Andi Offset

Winkel. (1996). Psikologi Pengajaran. Yogyakarta: Rasindo

Slameto.2010.Belajar dan Faktor-faktor yang Mempengaruhi.Jakarta:Rineka Cipta.

Syah,Muhibbin.2011.Psikologi Pendekatan Dengan Pendekatan Baru.Bandung:PT Remaja Rosda Karya Offset.

Uno,Hamzah B.2009.Model Pembelajaran Menciptakan Proses Belajar Mengajar yang Kreatif dan Efektif.Jakarta:Bumi Aksara.

Walgito,Bimo.2005.Bimbingan dan Konseling (Studi dan Karir).Yogyakarta: C.V. Andi Offset. 